University of Michigan Law School University of Michigan Law School Scholarship Repository

2012

\title{
The Quest for a Sustainable Future and the Dawn of a New Journal at Michigan Law
}

David M. Uhlmann

University of Michigan Law School, duhlmann@umich.edu

Available at: https://repository.law.umich.edu/articles/784

Follow this and additional works at: https://repository.law.umich.edu/articles

Part of the Environmental Law Commons, Legal History Commons, Legislation Commons, and the Natural Resources Law Commons

\section{Recommended Citation}

Uhlmann, David M. "The Quest for a Sustainable Future and the Dawn of a New Journal at Michigan Law." Mich. J. Envtl \& Admin. L. 1, no. 1 (2012): 1-16.

This Essay is brought to you for free and open access by the Faculty Scholarship at University of Michigan Law School Scholarship Repository. It has been accepted for inclusion in Articles by an authorized administrator of University of Michigan Law School Scholarship Repository. For more information, please contact mlaw.repository@umich.edu. 


\title{
ESSAY
}

\section{THE QUEST FOR A SUSTAINABLE FUTURE AND THE DAWN OF A NEW JOURNAL AT MICHIGAN LAW}

\author{
David M. Uhlmann*
}

When I joined the faculty of the University of Michigan Law School in 2007, the first assignment I gave students in my Environmental Law and Policy class was John McPhee's Encounters with the Archdruid. ${ }^{1}$ It must have seemed like a curious choice to them, particularly coming from a professor who just three months earlier had been the Chief of the Environmental Crimes Section at the U.S. Department of Justice. The book was not a dramatic tale of courtroom battles. In fact, the book was not even about the law, and the clash of environmental values it depicted pre-dated the environmental statutes that were the focus of the course.

Encounters with the Archdruid chronicles outings McPhee organized during the 1960s with David Brower, the first Executive Director of the Sierra Club and one of the most influential environmental activists of his generation. ${ }^{2}$ Brower was an unapologetic advocate for conservation at a time when we still believed that anything was possible in the United States and that America had an endless bounty of natural resources to support economic growth. McPhee paired Brower with three antagonists who had very different ideas about our relationship with the environment: Charles Park, the former Dean of Stanford University's School of Earth Sciences and a proponent of mining in the Cascade mountains; ${ }^{3}$ Charles Fraser, the developer

* Jeffrey F. Liss Professor from Practice and the Director of the Environmental Law and Policy Program at the University of Michigan Law School. I would like to commend the founding board members of the Michigan Journal of Environmental \& Administrative Law and the journal staff for a superb inaugural issue of the journal. I also would like to thank Johanna Dennehy for providing outstanding research assistance for this introductory Essay.

1. John MCPhee, Encounters with the ArChdruid (1971).

2. E.g., Richard Severo, David Brower, an Aggressive Champion of U.S. Environmentalism, Is Dead at 88, N.Y. TIMES, Nov. 7, 2000, at C22 (describing Brower's influence on the American environmental movement in the latter half of the twentieth century). Brower was also the founder of Friends of the Earth, the League of Conservation Voters, and the Earth Island Institute. David Brower, DAVID BROWER CTR., http://www.browercenter.org/node/ 179 (last visited Oct. 22, 2011).

3. MCPHEE, supra note 1 , pt. 1. 
of Hilton Head Island in South Carolina, who had similar plans to develop Cumberland Island off the Georgia coast; ${ }^{4}$ and Floyd Dominy, the indomitable Commissioner of the Bureau of Reclamation, who wanted to dam the Colorado River near the Grand Canyon. ${ }^{5}$

The stories in Encounters with the Archdruid occurred more than forty years ago, but I assigned the book to my students both for historical context and because the disagreements it describes about our environmental values remain potent today. As they hiked in the Cascades, Brower and Park argued about whether copper mining should be allowed in protected wilderness near Glacier Peak. ${ }^{6}$ Brower observed that the Cascades are "one of the few remaining great wildernesses in the lower forty-eight" and asked, "Would America have to go without much to leave its finest wilderness unspoiled?" 8 Park countered that " $[\mathrm{m}]$ inerals are where you find them. The quantities are finite. It's criminal to waste minerals when the standard of living of your people depends upon them." "For anyone who has followed the debate over proposals to drill in the Arctic National Wildlife Refuge (ANWR), ${ }^{10}$ the conflict and the language are familiar (only now the argument is about oil rather than copper, and the wilderness is in Alaska instead of Washington).

Brower and Fraser contemplated whether development of the largely uninhabited Cumberland Island could occur in a way that preserved the unique qualities of the ecosystem. Brower asserted that conservation should be "an ethic and conscience in everything we do"11 and posited that roughly ninety percent of the earth had been developed in some way and the remaining ten percent should be left alone. ${ }^{12}$ Fraser viewed Brower and other environmental leaders as "modern druids [who] worship trees and sacrifice

4. Id. pt. 2.

5. Id. pt. 3.

6. Id. at 4-5. Kennecott Copper Corporation had proposed to mine in the Cascades under provisions of the Wilderness Act that provided a twenty-year exemption for historical mining claims. Wilderness Act of $1964 \S 4$ (d)(3), 16 U.S.C. $\S \S 1131-1136$ (2006).

7. MCPheE, supra note 1 , at 21.

8. Id. at 23 .

9. Id. at 21 .

10. See, e.g., Robert Hahn \& Peter Passell, Op-Ed., Save the Environment: Drill, Baby, Drill, N.Y. TIMES, Sept. 15, 2008, at A25 (arguing that drilling in ANWR makes both political and environmental sense because politicians could appear responsive to public outcry over high gas prices and the profits could be used to fund preservation of other wilderness areas); Charles Krauthammer, Op-Ed., A Disaster with Many Fathers, WASH. POST, May 28, 2010, at A25 (arguing that environmentalists are at least partially responsible for the Gulf oil spill because their opposition to drilling in ANWR and off the Atlantic and Pacific coasts has forced oil companies to drill ever deeper wells in the Gulf of Mexico).

11. MCPHEE, supra note 1 at 83.

12. Id. at $84-85$. 
human beings to those trees."13 Brower and Fraser managed to agree on a formula for the development of Cumberland Island that would have banned cars from the island ${ }^{14}$ and preserved most of the island as a National Seashore $^{15}$ (a reversal of Brower's ninety/ten formula that would have allowed development of ten percent of the island and left the remaining ninety percent untouched). The development never took place-Fraser eventually sold his property on Cumberland Island to the National Park Founda$\operatorname{tion}^{16}$ - but the dialogue between Brower and Fraser raised the possibility of a conservation ethic that foreshadowed current efforts to promote sustainable land use. ${ }^{17}$

Brower and Dominy were adversaries long before $\mathrm{McPhee}$ invited them to raft together down the Colorado River. Brower was an ardent opponent of dam construction, ${ }^{18}$ a practice that Dominy, as Commissioner of the Bureau of Reclamation, had championed to make water more widely available in the arid West. Brower and Dominy held diametrically opposing views of the environment. Dominy explained that "too many people think of environment simply as untrammelled nature." ${ }^{19}$ As they toured Lake Powell, which was formed when a dam was created over what was once Glen Canyon, Dominy stated, "Let's use our environment. Nature changes the environment every day of our lives - why shouldn't we change it? We're part of nature." ${ }^{20}$ Brower responded, "You can't duplicate this experiencethis lake-anywhere else. But neither can you enjoy the original experience. That's the trouble .... The ibis, the egrets, the wild blue herons are gone. Their habitat is gone." ${ }^{21}$ Similar debates continue today in the American West: farming communities rely on dam use to provide water for irrigation, while Indian groups and environmentalists contend that dams are silting

13. Id. at 95 .

14. Id. at 122 .

15. Id.

16. Id. at 149. The National Park Foundation is a Congressionally-chartered charitable organization established in 1967 to support the activities of the National Park Service. 16 U.S.C. $\S 19 \mathrm{e}$ (2006).

17. As early as 1949, Aldo Leopold provided the intellectual precursor to today's sustainable development movement. In an essay entitled The Land Ethic, Leopold famously stated, "A thing is right when it tends to preserve the integrity, stability, and beauty of the biotic community. It is wrong when it tends otherwise." Aldo LEOPOLD, A SAND COUNTY ALMANAC 262 (1949).

18. MCPHEE, supra note 1 , at 158-59.

19. Id. at 171 .

20. Id. at 173 .

21. Id. at 198. 
rivers and preventing salmon from returning to their spawning grounds, thus wreaking havoc on ecosystems that depend upon salmon. ${ }^{22}$

Encounters with the Archdruid was published in 1971, just as the American environmental movement was reaping its greatest success and the modern administrative law system was in its infancy. ${ }^{23}$ The National Environmental Policy Act was enacted in $1969,{ }^{24}$ leading to the creation of the Council on Environmental Quality ${ }^{25}$ and requiring Environmental Impact Statements for all proposed "legislation and other major Federal actions significantly affecting the quality of the human environment." ${ }^{26}$ The Clean Air Act amendments in $1970^{27}$ and the Clean Water Act amendments in $1972^{28}$ dramatically changed how we addressed air and water pollution and put the federal government at the forefront of pollution control in ways that would have been inconceivable even a decade earlier. The Endangered Species Act of $1973^{29}$ provided unprecedented protection for the critical habitat of endangered and threatened species. The Resource Conservation and Recovery Act of $1976^{30}$ and the Comprehensive Environmental Response, Compensation, and Liability Act of $1980^{31}$ brought sweeping changes to waste management practices and created retroactive liability for past waste disposal.

22. See, e.g., Kandra v. United States, 145 F. Supp. 2d 1192 (D. Or. 2001); Klamath Irrigation Dist. v. United States, 67 Fed. Cl. 504, 509-13 (2005); see also Dean E. Murphy, Judge Orders Change in Plan to Distribute Klamath River Water, N.Y. TIMES, July 18, 2003, at A12 (describing arguments made by opposing parties in Klamath dispute).

23. See generally Richard B. Stewart, The Reformation of American Administrative Law, 88 HARV. L. REV. 1667 (1975) (describing the transformation of American administrative law as moving away from the traditional model, in which agency actions were limited by statutory directives and subject to stringent judicial review, and moving toward a model that acknowledged that agencies exercise broad discretion in creating rules that affect private liberty and property interests).

24. Pub. L. No. 91-190, 83 Stat. 852 (codified as amended at 42 U.S.C. $\S \S 4321-$ $4370 \mathrm{~h}(2006))$.

25. Id. $\S 202$.

26. Id. $\S 102(\mathrm{C})$.

27. Pub. L. No. $91-604,84$ Stat. 1676 (codified as amended at 42 U.S.C. $\S \S 7401-$ $7671 \mathrm{q}(2006))$.

28. Pub. L. No. 92-500, 86 Stat. 816 (codified as amended at 33 U.S.C. $\S \S 1251-1387$ (2006)).

29. Pub. L. No. $93-205,87$ Stat. 884 (codified as amended at 16 U.S.C. $\S \S 1531-1544$ (2006)).

30. Pub. L. No. $94-580,90$ Stat. 2795 (codified as amended at 42 U.S.C. $\S \S 6901-$ $6992 \mathrm{k}(2006))$.

31. Pub. L. No. $96-510,94$ Stat. 2767 (codified as amended at 42 U.S.C. $\S \S 9601-9675$ $(2006))$. 
During the course of the 1970s and 1980s, more than two dozen environmental and natural resource statutes were enacted by Congress. ${ }^{32}$ Most passed with nearly unanimous support-margins that would be unthinkable today - and many were signed into law by Republican presidents. ${ }^{33}$ To some extent, the success of the environmental movement during the 1970 s and 1980s may have reflected a need for consensus in the United States after the battles of the civil rights movement, the upheaval of women's liberation, and the divisiveness of the Vietnam War. ${ }^{34}$ Moreover, the events that motivated Congress to enact environmental laws had appeal across partisan lines. Shock over the Santa Barbara oil spill in California and the burning Cuyahoga River in Ohio, ${ }^{35}$ concern about evacuated communities in upstate New York ${ }^{36}$ and Missouri, ${ }^{37}$ and distress over images of contaminated valleys with thousands of drums of hazardous waste ${ }^{38}$ were not limited to members of one political party. The aspirations that everyone had a right to clean air, safe drinking water, and unpolluted land were goals that everyone could share, regardless of their political affiliations. ${ }^{39}$

Although broad-based support for environmental protection would prove fleeting, there is no question that the 1970s and the 1980s were a highwater mark for environmental law in the United States. Yet, even in those halcyon days, it is not clear that we ever achieved anything approaching

32. See Richard J. Lazarus, The Making of Environmental Law 69-73 (2004).

33. Id. at 69 ("The average vote in favor of major federal environmental legislation during the 1970 s was 76 to 5 in the Senate and 331 to 30 in the House, suggesting a broad bipartisan consensus.").

34. Richard J. Lazarus, The Greening of America and the Graying of United States Environmental Law: Reflections on Environmental Law's First Three Decades in the United States, 20 VA. ENVTL. L.J. 75, 79 (2001).

35. Id.

36. See, e.g., Eckardt C. Beck, The Love Canal Tragedy, EPA J., Jan. 1979, at 17, available at http://www.epa.gov/history/topics/lovecanal/01.html.

37. See, e.g., Sharon Cohen, Ex-Residents Pay Final Respects to Times Beach, A Town Ready for Burial, L.A. Times, Apr. 7, 1992, at 2, available at http://articles.latimes.com/199104-07/news/mn-30_1_times-beach.

38. See, e.g., Tom Gorman, A Tainted Legacy: Toxic Dump Site in Riverside County Has Sparked the Nation's Largest Civil Suit, L.A. TimES, Jan. 10, 1993, at A3, available at http:// articles.latimes.com/1993-01-10/news/mn-1588_1_riverside-county (discussing the Stringfellow Acid Pits); James Bruggers, Toxic Legacy Revisited: Valley of the Drums, 30 Years Later, COURIER-J. (Dec. 14, 2008, 4:07 AM), http:/www.courier-journal.com/article/20081214/ NEWS01/81214001\&referrer=FRONTPAGECAROUSEL.

39. As Theodore White observed, "the environment[al] cause had swollen into the favorite sacred issue of all politicians, all TV networks, all writers, all good-willed people of any party." Theodore WHITE, The MAKING OF THE President 1972, at 45 (1973). 
consensus about our underlying environmental values. At first blush, it might appear that Brower's ecological values had prevailed in the United States. To be sure, much was accomplished during the 1970s and 1980s, and not just in terms of lawmaking. We have cleaner air, ${ }^{40}$ fresher water, ${ }^{41}$ and far less hazardous waste ${ }^{42}$ today than we did forty years ago, and we have far more robust protection for wildlife, plants, and natural resources than even Brower might have envisioned.

But Brower had argued for a conservationist ethic where environmental protection was advanced for its own sake. He articulated an eco-centric approach to environmental values that would preserve wilderness, protect biodiversity, and require humans to live in better balance with their habitat. The United States, Brower argued, had six percent of the world's population but consumed sixty percent of the earth's resources. ${ }^{43}$ In a finite world, he insisted, we had to be prepared to live with less for future generations to thrive. ${ }^{44}$ His vision therefore was not just a conservation ethic, but an environmental value system focused on what we now know as sustainability.

Americans have not yet embraced environmental values based on ecological concerns or an environmental protection system that emphasizes sustainability. Instead, ours has been a decidedly human-centric approach focused on the public health benefits of pollution prevention. The National Environmental Policy Act addresses adverse impacts on the human environment. ${ }^{45}$ We measure our success under the Clean Air Act in terms of public health effects and regulate under the Act when air pollution is found to endanger public health. ${ }^{46}$ We regulate wastes under the Resource

40. Air Quality Trends, EPA, http://www.epa.gov/airtrends/aqtrends.html (last updated Feb. 10, 2011).

41. EPA, PROGRESS IN WATER QUALITY 15-18 (2000), available at http://water.epa. gov/polwaste/wastewater/treatment/benefits.cfm (noting that tremendous progress has been made in improving water quality in nine sample waterways).

42. EPA, BENEFICIAL EFFECTS OF THE SUPERFUnd PROGRAM 17 (2011), available at http://www.epa.gov/superfund/accomp/pdfs/SFBenefits-031011-Ver1.pdf (noting that over the past twenty-five years, federal government programs remediated approximately 500,000 hazardous waste sites).

43. MCPHEE, supra note 1 , at 81.

44. Id. at 21 .

45. 42 U.S.C. $\$ 4332(\mathrm{C})$ (2006) (requiring Environmental Impact Statements for actions "significantly affecting the quality of the human environment").

46. See, e.g., 42 U.S.C. $\S 7401(b)$ (1) (2006) (noting that one of the purposes of this subchapter is "to protect and enhance the quality of the Nation's air resources so as to promote the public health and welfare"); 42 U.S.C. $\$ 7408(\mathrm{a})(1)(\mathrm{A})$ (2006) (requiring the listing of all air pollutants "emissions of which ... cause or contribute to air pollution which may reasonably be anticipated to endanger public health or welfare"); 42 U.S.C. $\S 7409$ (b) (2006) (requiring National Ambient Air Quality Standards at levels necessary for the "[p]rotection of public health and welfare"). 
Conservation and Recovery Act when they risk substantial potential harm to human health and the environment (in that order). ${ }^{47}$ Even the loftiest of our goals - the now quaint provision of the Clean Water Act guaranteeing an end to all point source discharges by 1985 and fishable and swimmable waters by $1983^{48}$ - focuses on human uses of our rivers and streams. The Endangered Species Act provides an exception to the human-first approach of our environmental laws, yet it has been pilloried in debates over the snail darter, desert tortoise, and northern spotted owl. ${ }^{49}$

The preeminence of human-centric values in our nation's environmental laws (as opposed to the eco-centric values advocated by Brower) is underscored by administrative law requirements that often place economic values over environmental concerns. Beginning in the Reagan Administration-and continuing with every President since-federal agencies have been required to conduct cost-benefit analyses for all new rules that have an estimated economic impact over $\$ 100$ million. ${ }^{50}$ Their assessments are subject to further review by the Office of Management and Budget (OMB), which must clear proposed rules before they can be published in the Federal Register for public comment. ${ }^{51}$ In addition, even before OMB review, administrative agencies focus on scientific and technical comments about proposed rules at the expense of a values-based approach that might allow for greater emphasis on environmental and ecological concerns. ${ }^{52}$

Cost-benefit analysis may have a necessary role in the rule-making process, particularly for regulations that are enacted to address commercial interests such as preserving fair competition or providing stability in financial markets. ${ }^{53}$ In those contexts, where economic concerns are at the heart of the proposed regulation, it may be reasonable to weigh heavily economic

47. 42 U.S.C. $\S 6903(5)$ (B) (2006) (defining hazardous waste to include solid waste that may "pose a substantial present or potential hazard to human health or the environment").

48. $\quad 33$ U.S.C. $§ 1251(1)-(2)(2006)$.

49. See, e.g., Frank Clifford, 6.4 Million Acres to Be Designated Tortoise Habitat, L.A. Times, Feb. 8, 1994, at A1; Timothy Egan, Politics Reign at Spotted Owl Hearing, N.Y. TIMES, Jan. 9, 1992, at A14; Margot Hornblower, Carter Signs Bill Forcing Tellico Dam Completion, WASH. POST, Sept. 26, 1979, at A2.

50. See, e.g., Exec. Order No. 12,291, 3 C.F.R. 127 (1982) (Reagan); Exec. Order No. 12,866, 3 C.F.R. 638 (1994) (Clinton).

51. See 3 C.F.R. 638 .

52. See Nina A. Mendelson, Rulemaking, Democracy, and Torrents of Email, 79 GEO. WASH. L. REV. 1343 (2011). Of course, broader consideration of values-based comments would not necessarily lead to greater concern for environmental values. The present approach of our administrative law system, however, forecloses even the possibility that ecological values will be emphasized in the rule-making process.

53. See, e.g., Edward Sherwin, The Cost-Benefit Analysis of Financial Regulation: Lessons from the SEC's Stalled Mutual Fund Reform Effort, 12 STAN. J.L. BUS. \& FIN. 1 (2006). 
costs and benefits of the proposed regulations. Cost-benefit analysis may also provide a useful metric for analyzing the benefits of proposed regulations that focus exclusively on public health and safety-for example, in determining the lives saved or injuries prevented by requiring side-impact air bags in cars. ${ }^{54}$

As numerous scholars have argued, however, cost-benefit analysis is a poor analytical fit when the benefits of proposed regulations cannot be monetized, as often is the case under laws protecting the environment and natural resources. ${ }^{55}$ We have no way of putting an accurate price tag on the ecological value of protecting the critical habitat of wildlife or taking the steps needed to assure long-term planetary health. The valuation problem becomes even greater when the ecological benefits are not obvious to humans, as with the protection of life forms far down the food chain or with ecologically diverse marshes and swamps that play an essential role in pollution reduction but appear to be little more than mosquito breeding grounds to many humans.

Nor is it clear that we are any better at monetizing the costs of environmental regulations. Automobile manufacturers notoriously insisted that the phaseout of leaded gasoline in the 1970s and efforts to reduce pollution from motor vehicles would lead to the demise of the domestic car industry $;^{57}$ instead, those regulatory efforts led to the development of the catalytic converter with far less economic dislocation than originally feared. ${ }^{58}$ After Congress passed the Clean Air Act Amendments of 1990, which required efforts to address acid rain, ${ }^{59}$ industry complained loudly

54. Cf. John D. Graham, Saving Lives Through Administrative Law and Economics, 157 U. PA. L. REV. 395, 450 (arguing that OMB has used cost-benefit analysis to "enhance[] the lifesaving impact of federal regulation").

55. See, e.g., Frank Ackerman \& Lisa Heinzerling, Pricing the Priceless: Cost-Benefit Analysis of Environmental Protection, 150 U. PA. L. REv. 1553 (2002); Thomas O. McGarity, Professor Sunstein's Fuzzy Math, 90 GEO. L.J. 2341 (2002); Amy Sinden, The Economics of Endangered Species: Why Less Is More in the Economic Analysis of Critical Habitat Designations, 28 Harv. EnvTl. L. Rev. 129 (2004); see also Douglas A. KySAR, Regulating From NOWHERE: ENVIRONMENTAL LAW AND THE SEARCH FOR OBJECTIVITY (2010).

56. See, e.g., James Salzman, Valuing Ecosystem Services, 24 ECOLOGY L.Q. 887 (1997) (describing the difficulty of assigning a monetary value to an ecosystem).

57. See Michael Weisskopf, Auto-Pollution Debate Has Ring of the Past; Despite Success, Detroit Resists, WASH. POST, Mar. 26, 1990, at A1 (describing auto industry resistance to new pollution control standards in the 1970s).

58. See id.

59. Clean Air Act Amendments of 1990, Pub. L. No. 101-549, § 401, 104 Stat. 2584, 2584-85 (codified as amended at 42 U.S.C. $\S 7651(2006)$ ). 
that the costs would be devastating for American manufacturing. ${ }^{60}$ Yet installation of scrubbers and other pollution controls in factories reduced emissions at a fraction of the anticipated cost. ${ }^{61}$

The role of cost-benefit analysis in the regulatory process is the best example of how we place economic concerns above environmental interests, but the problem goes much further. We could subject new regulations to cost-benefit analysis as a procedural matter, so that we are mindful of the potential costs of new regulations and the extent to which the possible benefits could be monetized, yet still move forward with regulations that serve to ensure broader environmental protection and promote long-term sustainability. Instead, economic concerns trump environmental priorities in our lawmaking and our regulatory procedures, much as the economy wins out time and again when it is pitted against the environment in the electoral process. ${ }^{62}$

Perhaps as a result of our human-centric approach to environmental protection, our environmental laws are now badly outdated, and we continue to lack agreement about how to reconcile conservation and the needs of an industrialized society. We had an "environmental moment" in the 1970s that led to the enactment of a system of laws that, even if they did not reflect a more eco-centric value system, went a long way toward addressing the human health and aesthetic concerns that fueled the environmental movement. We amended those laws in the 1980s, expanding their reach and enhancing the government's ability to enforce the law (including stronger criminal penalties for serious violations). ${ }^{63}$ But we have not engaged in any significant environmental lawmaking since the Clean Air Act Amendments of 1990 were signed into law by President George H. W. Bush.

60. See Barnaby J. Feder et al., The Struggle in Congress; Focus Shifts to Rules on Cleaner Air For Car, Chemical and Steel Makers, N.Y. TimEs, Oct. 24, 1990, at A21 (describing industry claims that the 1990 amendments would prove extremely costly).

61. Nat'l Sci. \& Tech. Council, National Acid Precipitation Assessment PRogram Report To Congress: An INTEgrated Assessment 12 (2005) (noting that the costs of implementing the acid rain program were substantially less than predicted in 1990).

62. See, e.g., MacKenzie Carpenter, Gas Prices Open Door for McCain, PITTsburgi POST-GAZETTE, June 29, 2008, at A1 (describing how Republicans capitalized on voter frustration with high gas prices to demand more domestic drilling during the 2008 election). Even worse from an environmental perspective is the fact that Americans now favor development of new sources of energy even if it results in harm to the environment. Jeffrey $M$. Jones, Americans Prioritize Energy Over Environment for First Time, Gallup, Apr. 6, 2010, available at http://www.gallup.com/poll/127220/americans-prioritize-energy-environmentfirst-time.aspx.

63. See David M. Uhlmann, Environmental Crime Comes of Age: The Evolution of Criminal Enforcement in the Environmental Regulatory Scheme, 2009 UTAH L. REV. 1223, 122728. 
During the last twenty years, as we have refrained from enacting new environmental protection laws, our environmental problems have grown more complex and far reaching. We now face the possibility of the greatest loss of biological diversity since the last Ice Age ${ }^{64}$-even as the potential for catastrophic climate change increases with each passing year. ${ }^{65}$ In the 2008 presidential election, then-Senator Barack Obama and Senator John $\mathrm{McC}$ ain both campaigned in favor of a cap-and-trade system to address global climate change. ${ }^{66}$ At that point, it appeared certain that we would have comprehensive climate change legislation in 2009 or 2010. But the prospects for climate change legislation have collapsed as economic growth has withered, ${ }^{67}$ despite the benefits for economic growth that would accompany the development of alternative energy sources needed to combat climate change. ${ }^{68}$

In the face of congressional inaction on climate change, the Environmental Protection Agency (EPA) has begun to use its Clean Air Act authority to limit greenhouse gas emissions. In a belated response to the Supreme Court's decision in Massachusetts v. EPA, ${ }^{69}$ the Agency determined in 2009 that greenhouse gas emissions are endangering public health and the environment. ${ }^{70}$ Based on its endangerment finding, EPA initiated a trio of regulatory actions aimed at reducing greenhouse gases: (1) limits on

64. See, e.g., Food \& AGric. Org. OH The United Nations, Livestock's LoNG SHADOw: ENVIRONMENTAL ISSUES AND OptIONS 182 (2006), available at http://www. fao.org/docrep/010/a0701e/a0701e00.htm.

65. See United nations intergovernmental Panel on Climate Change, CLimATE CHANGE 2007, at 13 (2007), available at http://www.ipcc.ch/pdf/assessment-report/ ar4/syr/ar4_syr_spm.pdf (noting that anthropogenic warming could lead to some impacts that are abrupt or irreversible); Elisabeth Rosenthal, U.N. Report Describes Risks of Inaction on Climate Change, N.Y. Times, Nov. 17, 2007, at A1.

66. Andrew C. Revkin, On Global Warming, McCain and Obama Agree: Urgent Action is Needed, N.Y. Times, Oct. 19, 2008 at A22.

67. Elisabeth Rosenthal, Where Did Global Warming Go?, N.Y. TIMES, Oct. 16, 2011, at SR1. For a good summary of the failed legislative efforts to address climate change, see 111th Congress Climate Change Legislation, CTR. HOR Climate Change \& ENERGY SOlutions, http://www.pewclimate.org/federal/congress/111 (last visited Oct. 17, 2011).

68. Nancy Folbre, The Green Jobs Numbers, ECONOMIX (Sept. 12, 2011, 6:00 AM), http://economix.blogs.nytimes.com/page/7/.

69. 549 U.S. 497 (2007) (holding that greenhouse gases fall within the Clean Air Act's "capacious definition" of air pollutants and that EPA must base its decision about whether to regulate on the statute).

70. See Endangerment and Cause or Contribute Findings for Greenhouse Gases Under Section 202(a) of the Clean Air Act, 74 Fed. Reg. 66,496 (Dec. 15, 2009) (to be codified at 40 C.F.R. pt. 1). 
greenhouse gas emissions from automobiles; ${ }^{71}$ (2) reporting requirements that will enable the Agency to inventory sources of greenhouse gases; ${ }^{72}$ and (3) limits on greenhouse gas emissions from large stationary sources such as factories and refineries. ${ }^{73}$ Yet there is growing support in Congress for curtailing EPA's authority to regulate greenhouse gas emissions under the Clean Air Act and for defunding the Agency's efforts to address climate change. $^{74}$

Perhaps even more alarming is the degree to which the ascendancy of the Tea Party has led to increasingly shrill calls to curtail EPA authority more broadly, up to and including proposals to eliminate EPA altogether. ${ }^{75}$ The argument that environmental protection hampers economic growth has its roots in the Reagan administration, which sought to limit EPA's authority, only to be outmaneuvered by Democrats in Congress, who enacted sweeping amendments to the environmental laws to expand environmental enforcement. ${ }^{76}$ Similar calls to limit EPA authority emerged as part of the

71. See Light-Duty Vehicle Greenhouse Gas Emission Standards and Corporate Average Fuel Economy Standards, 75 Fed. Reg. 25,324 (May 7, 2010) (to be codified at 40 C.F.R. pts. 85, 86).

72. See Mandatory Reporting of Greenhouse Gases, 74 Fed. Reg. 56,260 (Oct. 30, 2009) (to be codified in scattered parts of 40 C.F.R.).

73. See Prevention of Significant Deterioration and Title V Greenhouse Gas Tailoring Rule, 75 Fed. Reg. 31,514 (Jun. 3, 2010) (to be codified at 74 C.F.R. pts. 51-52, 71-72).

74. See Consumer Relief for Pain at the Pump Act, H.R. 1777, 111th Cong. $\$ 301$ (2011) (calling for the repeal of EPA climate change regulation under the Clean Air Act, NEPA, etc.); Energy Tax Prevention Act of 2011, H.R. 910, 111th Cong. (2011) (proposing to "amend the Clean Air Act to prohibit the Administrator of the EPA from promulgating any regulation concerning, taking action relating to, or taking into consideration the emission of a greenhouse gas to address climate change, or for other purposes"); Energy Tax Prevention Act of 2011, S. 482, 111th Cong. (2011) (proposing to "amend the Clean Air Act to prohibit the Administrator of the EPA from promulgating any regulation concerning, taking action relating to, or taking into consideration the emission of a greenhouse gas to address climate change, or for other purposes"); The Energy Production Freedom Act, H.R. 1292, 111th Cong. (2011) (proposing to "amend the Clean Air Act to provide that greenhouse gases are not subject to the Act").

75. John M. Broder, Bashing E.P.A. is New Theme in G.O.P. Race, N.Y. TIMES, Aug. 18, 2011, at A1; Leslie Kaufman, House Republicans Try to Curb Environmental Rules, N.Y. TIMES, July 28, 2011, at A16.

76. See, e.g., Robert Pear, House Passes Bill to Widen Cleanup of Toxic Wastes, N.Y. Times, Aug. 11, 1984, at 1 (describing how the House of Representatives passed a bill expanding the EPA's Superfund program despite the Reagan administration efforts to weaken it); Philip Shabecoff, House Votes Stronger Clean Drinking Water Act, N.Y. TIMES, Jun. 18, 1985, at A21 (describing how the House and the Senate both passed bills that renewed and expanded the Safe Drinking Water Act, despite the fact that the Reagan administration was highly critical of the legislation). 
"Contract with America" in the 1990s. ${ }^{77}$ Those efforts were undone when Republicans overplayed their hand, shutting down the federal government and losing the support of the electorate. ${ }^{78}$

It remains to be seen whether the current backlash against environmental protection will fail as it did in the 1980s and 1990s. The prospect of a double-dip recession could lead our political leaders to waver in their support for environmental priorities. As President Obama's support has slipped, so too has his administration's resolve to address environmental concerns. The President's budget for 2012 proposed a thirteen percent cut in EPA's funding, ${ }^{79}$ even before the debate about debt limits and budget deficits put unprecedented pressure on the federal government to cut spending. ${ }^{80}$ EPA delayed implementation of regulations under the Clean Air Act that would limit greenhouse gas emissions from stationary sources until 2013. ${ }^{81}$ Most recently, President Obama directed EPA to suspend efforts to impose stricter National Ambient Air Quality Standards for ozone under the Clean Air Act, ${ }^{82}$ despite overwhelming scientific evidence that more stringent limits were necessary to protect public health and the environment. $^{83}$

77. See Frank Clifford, Bill Would Limit Federal Power Over Environment, L.A. TimEs, Dec. 28, 1994, at A1 ("The [Job Creation and Wage Enhancement Act] would require the U.S. Environmental Protection Agency and a host of other federal agencies . . . to shoulder a substantial share of the costs of regulation now borne by state and local governments and private enterprise.").

78. See Helen Dewar \& Eric Pianin, Concession Supersedes Revolution; GOP Attempts to Appease Voters, WASH. POST, Sept. 29, 1996, at A1.

79. Office of Mgmt. \& Budget, Exec. Office of the President, Fiscal Year 2012 BUDGET OF THE U.S. GOVERNMENT 145 (2011), available at http://www.whitehouse. gov/sites/default/files/omb/budget/fy2012/assets/message.pdf.

80. See Rosalind S. Helderman \& Felicia Sonmez, Pressure Mounts for Debt Panel, WASH. POST, Aug. 14, 2011, at A1 (describing the makeup of the congressional "supercommittee" tasked with cutting the deficit by at least $\$ 1.2$ trillion over the next ten years); Carl Hulse, After Snips to Budget, a Thicket Looms, N.Y. TIMES, June 18, 2011, at A12 (describing the pressure on lawmakers to significantly cut federal spending as part of the debt deal).

81. Change to the Reporting Date for Certain Data Elements Required Under the Mandatory Reporting of Greenhouse Gases Rule, 76 Fed. Reg. 53,057 (Aug. 25, 2011) (to be codified at 40 C.F.R. pt. 98).

82. See Barack Obama, Statement by the President on the Ozone National Ambient Air Quality Standards (Sept. 2, 2011), http://www.whitehouse.gov/the-press-office/2011/09/02/ statement-president-ozone-national-ambient-air-quality-standards (requesting that the EPA delay implementation of the Ozone National Ambient Air Quality Standards until 2013); News Release, Statement by EPA Administrator Lisa P. Jackson on the Ozone National Ambient Air Quality Standards (Sept. 2, 2011), http://yosemite.epa.gov/opa/admpress.nsf/0/ E41FBC47E7FF4F13852578FF00552BF8 (acceding to the President's request).

83. See National Ambient Air Quality Standards for Ozone, 75 Fed. Reg. 2938 (Jan. 19,2010 ) (to be codified at 40 C.F.R. pts. 50, 58). 
A generation after the dawn of the environmental movement, we have come full circle. Forty years ago, we faced pollution challenges that raised significant ecological and public health concerns. Today, climate change, depletion of natural resources, and loss of biodiversity threaten our ability to thrive on the planet. As in Brower's time, we must choose between meeting our needs, at the expense of the planet, and altering our behavior to promote long-term sustainability for all species.

But forty years ago our environmental challenges were readily apparent and could be addressed by immediate pollution prevention measures, like implementing a permit system for discharges into rivers and streams. ${ }^{84}$ Today, the problems we face also require immediate action, but much of the harm from failing to act will not be visited upon us until the latter half of this century, long after we can avoid it. ${ }^{85}$ Whether our society is psychologically and institutionally capable of making necessary changes today to stave off ecological disaster forty years from now is far from certain. Compounding matters, we no longer have the consensus about environmental protection that we enjoyed in the 1970 s, which further dims the prospects for meaningful environmental action.

Rethinking our approach to environmental protection and the proper balance between environment and economy is essential to a sustainable future. From the early years of the environmental movement, ecological economists have argued that we must view environment and economy in unison rather than in opposition. ${ }^{86}$ Whether their prescription for lower growth and more stringent limits on resource use is correct or not, our economy cannot remain strong if we continue to deplete the Earth's resources at such an alarming rate and fail to protect our habitat in ways that will allow our species to survive. Nor is the argument for change simply a matter of environment and economics. From a moral and religious perspective, we have an obligation to chart a path that preserves the Earth's

84. 33 U.S.C. $\S 1342$ (2006) (establishing the National Pollutant Discharge Elimina tion System).

85. See Intergovernmental Panel on Climate Change, ipCC Fourth Assessment Report: Climate Change $2007 \S 10.7 .1$ (2007), available at http://www. ipcc.ch/publications_and_data/ar4/wg1/en/ch10s10-7.html (describing the concept of time lag in global warming); see also ElizABETH KOLBERT, FIELD NOTES FROM A CATASTROPHE 106-08 (2006) (noting that if greenhouse gases were held constant at current levels, it is estimated that it would take several decades for the effects of current human actions on the climate to be felt).

86. See, e.g., Herman E. Daly \& John B. Cobb, JR., For the Common Good: REDIRECTING THE ECONOMY TOWARD COMMUNiTY, THE ENVIRONMENT, AND A Sustainable Future (2d ed. 1994). 
ecological treasures for future generations and to sustain life for species other than our own. ${ }^{87}$

With so much at stake, it would be asking too much to expect a new law journal to solve the environmental challenges we face in this new millennium. Yet the University of Michigan Law School has a long history of leadership where environmental issues are concerned. In the 1960 s and 1970s, Michigan Law Professor Joseph Sax was a leading academic voice on environmental protection, with a profound influence on the development of the environmental law system in the United States. ${ }^{88}$ His students went on to leadership roles in a wide range of environmental organizations and in government, ${ }^{89}$ helping Michigan Law play a preeminent role in the environmental successes we have enjoyed over the last forty years.

In 2007, Michigan Law created the Environmental Law and Policy Program (ELPP) to draw on the Law School's rich tradition of leadership on environmental issues and the interdisciplinary strengths of the University of Michigan in addressing today's environmental challenges. ${ }^{90}$ ELPP has a strong public service and public interest emphasis, promoting engagement

87. See, e.g., Peter Singer, Practical Ethics 264-88 (1993) (arguing that our decisions on how to use environmental resources must account for effects on future generations of humans and other beings); THE Evangelical Climate Initiative, Climate Change: An EvangeliCal CALL TO ACTION (2006), available at http:/www.npr.org/ documents/2006/feb/evangelical/calltoaction.pdf (providing an evangelical Christian perspective on our obligation to preserve the environment for future generations); Soc. Justice \& Ecology Secretariat, Healing a Broken World, PROMOTIO IUSTITIAE, no. 106, 2011 (exploring sustainability from a Jesuit perspective).

88. See, e.g., Lazarus, supra note 34, at 82 ("Professor Joseph Sax's early scholarship provided much of the strategic blueprint followed by the environmental public interest groups.").

89. Two of Professor Sax's former students who assumed leadership roles in national environmental organizations are Fred Krupp, the current President of the Environmental Defense Fund, see Fred Krupp, ENVTL. DEF. Fund, http://www.edf.org/people/fred-krupp (last visited Oct. 23, 2011), and Mark Van Putten, former President and CEO of the National Wildlife Federation, see Mark Van Putten, J.D., ConservationStrategy LLC, http://www.conservationstrategy.com/markvanputten.html (last visited Oct. 23, 2011). A third former student who played a leadership role in government is James Moorman, who served as Assistant Attorney General for the Lands and Natural Resources Division during the Carter administration. U.S. DeP'T. OF Justice, Env'T \& Natural Res. Div., Public Lands \& National Treasures: The First 100 Years of the Environment and NATURAL RESOURCES DiviSION, 1909-2009, at 49-51, 59 (2009), available at http://www. justice.gov/enrd/ENRD_Assets/public_lands_and_national_treasures.pdf.

90. See Environmental Law and Policy Program, U. MiCH. L. SCH., http://www.law. umich.edu/centersandprograms/elpp/Pages/default.aspx (last visited Sept. 19, 2011). 
between academia and community initiatives to bring renewed attention to environmental problems and the need for new approaches to environmental protection. In September 2008, ELPP sponsored a conference entitled "The Environmental Agenda for the Next Administration," which featured a keynote address by then-Governor Jennifer M. Granholm and panel discussions focusing on climate change, alternative energy, and sustainability. ${ }^{91}$ In April 2010, ELPP explored the critical relationship between environmental protection and economic priorities and considered how we might better balance them in a conference entitled "Environmental Law and Economics." In March 2012, ELPP will host the twenty-fifth annual conference of the National Association of Environmental Law Societies, with a focus on developments in environmental law over the last twentyfive years and the challenges that we face over the next twenty-five years. ${ }^{93}$

The heart of Michigan Law's environmental program since its inception in 2007 has been our students. Student interest in environmental issues spurred the creation of ELPP and has continued to grow over the last five years. The law school has responded by expanding its environmental curriculum to include approximately twenty courses every year, among the most extensive course offerings of any top law school in the United States. ${ }^{94}$ Meanwhile, Michigan Law students have demonstrated commitment to addressing the environmental challenges facing our world, even as national efforts to address environmental problems have stalled.

The creation of the Michigan Journal of Environmental $\mathcal{E}^{3}$ Administrative Law is further evidence of the intellectual engagement of Michigan Law students. The Michigan Journal of Environmental $\mathcal{E}$ Administrative Law is the first new journal at Michigan Law in more than a decade. Its provisional approval by the Law School resulted from years of advocacy by our environmental law students. In addition, our new journal reflects the increased awareness of sustainability issues across the University of Michigan campus and the importance of interdisciplinary efforts to address the challenges we face. In that regard, the Law School and the founders of the journal are grateful for the financial support provided by the Graham Environmental Sustainability Institute, ${ }^{95}$ which has underwritten the journal for its three years of provisional status.

91. Id.

92. Id.

93. See NAELS Conference 2012, NAT'L ASS'N ENVTL. L. SOC'YS, http://www.naels.org/ content/naels-conference-2012 (last visited Oct. 18, 2011).

94. See Environmental Law and Policy Program, supra note 90.

95. See GRAhAM ENVTL. SustainabilitTy InST., http://www.graham.umich.edu (last visited Sept. 19, 2011). 
In choosing to address both environmental law and administrative law, the student founders of the Michigan Journal of Environmental $\&$ Administrative Law have sought to build on the degree to which environmental law has shaped the development of administrative law - and the extent to which the success of any regulatory system depends upon thoughtful consideration of issues of administrative law, including the process by which regulations are promulgated and revised, as well as the procedures that govern their effective implementation and enforcement. Our students aim to publish a journal that takes an approach that is unique among environmental law journals and, in the process, to promote new scholarship and the development of sound public policy approaches in both environmental law and administrative law.

The Michigan Journal of Environmental $\mathcal{E} 3$ Administrative Law publishes its first issue at a time when our environmental challenges have never been greater. With those challenges, however, come opportunities to conceive new ideas that may promote sustainability in ways that have eluded us in the past. How might we rethink our approach to the environment and the economy to ensure a sustainable future? How should we transform our administrative law system so that it can better address long-term problems? What are the environmental values that should guide us in the new millennium? Our students could be pessimistic, given the enormity of the problems that confront our nation and the world. Instead, they are embracing the future with optimism and hope-and imagining a world that promotes the virtues of sustainability. Their efforts in the pages that follow - and in the years ahead-offer the promise of a brighter future for all inhabitants of the Earth. 